\title{
Synthesis and stability of Oligonucleotides Containing Acyclic Achiral Nucleoside Analogues With Two Base Moieties
}

\author{
Tongfei Wu, Matheus Froeyen, Guy Schepers, Kristof Mullens, Jef Rozenski, Roger \\ Busson, Arthur Van Aerschot, and Piet Herdewijn* \\ Laboratory of Medicinal Chemistry, Rega Institute for Medicinal Research, Katholieke Universiteit \\ Leuven, Minderbroedersstraat 10, B-3000 Leuven, Belgium
}

Piet.Herdewijn@rega.kuleuven.ac.be

Received Date (will be automatically inserted after manuscript is accepted)

\section{SUPPORTING INFORMATION}

\section{EXPERIMENTS}

For all reactions, analytical grade solvents were used. All moisture-sensitive reactions were carried out in oven-dried glassware $\left(135^{\circ} \mathrm{C}\right)$ under a nitrogen atmosphere. Anhydrous solvent THF was refluxed on sodium / benzophenone and distilled. A Varian Unity $500 \mathrm{MHz}$ spectrometer or a $200 \mathrm{MHz}$ Varian Gemini apparatus were used for ${ }^{1} \mathrm{H}$ NMR and ${ }^{13} \mathrm{C}$ NMR. Exact mass measurements were performed on a quadrupole time-of-flight mass spectrometer (Q-Tof-2, Micromass, Manchester, UK) equipped with a standard electrospray-ionization (ESI) interface; samples were infused in i-PrOH/ $\mathrm{H}_{2} \mathrm{O}$ 1:1 at $3 \mu \mathrm{L} / \mathrm{min}$. Precoated aluminum sheets (Fluka Silica gel/TLC-cards, 254nm) were used for TLC; The spots were examined with UV light. Column chromatography was performed on ICN silica gel 63-200 60^.

[5,5 -Bis-[(3-benzoyl-thymin-1-yl)methyl] -2-phenyl-1,3-dioxane (2a). To a mixture of 1a (5.0 g, 22.3 mmol), $\mathrm{N}^{3}$-benzoyl thymine $(10.3 \mathrm{~g}, 44.6 \mathrm{mmol})$ and $\mathrm{PPh}_{3}(11.7 \mathrm{~g}, 44.6 \mathrm{mmol})$ in dry THF $(200 \mathrm{~mL})$ under $\mathrm{N}_{2}$ at r.t. was added a solution of DEAD $(7.0 \mathrm{~mL}, 44.6 \mathrm{mmol})$ in dry THF $(20 \mathrm{~mL})$ over a period of $45 \mathrm{~min}$. The reaction mixture was stirred at r.t overnight, concentrated and the residue was chromatographed on silica gel (n-hexane:EtOAc, 2:1, then 1:1) to yield 2a (12.3 g) as a colorless amorphous solid in 85\% yield.. ${ }^{1} \mathrm{H}$ NMR $200 \mathrm{MHz}\left(\mathrm{CDCl}_{3}\right) \delta 1.88\left(3 \mathrm{H}, \mathrm{s}, \mathrm{T}-\mathrm{CH}_{3}\right), 1.93\left(3 \mathrm{H}, \mathrm{s}, \mathrm{T}-\mathrm{CH}_{3}\right)$, $3.77\left(2 \mathrm{H}, \mathrm{s}, \mathrm{CH}_{2}-\mathrm{N}\right), 3.98\left(2 \mathrm{H}, \mathrm{d}, J=12.2 \mathrm{~Hz}, \mathrm{CH}_{\mathrm{a}} \mathrm{O}\right), 4.06\left(2 \mathrm{H}, \mathrm{d}, J=12.2 \mathrm{~Hz}, \mathrm{CH}_{\mathrm{b}} \mathrm{O}\right), 4.21(2 \mathrm{H}, \mathrm{s}$, $\left.\mathrm{CH}_{2}-\mathrm{N}\right), 5.54(1 \mathrm{H}, \mathrm{s}, \mathrm{Ph}-\mathrm{CH}), 7.26-7.93(17 \mathrm{H}, \mathrm{m}, \mathrm{T}-\mathrm{C}(6), \mathrm{Ar}-\mathrm{H}) ;{ }^{13} \mathrm{CNMR} 200 \mathrm{MHz}\left(\mathrm{CDCl}_{3}\right) \delta_{\mathrm{C}} 12.29$, 
$12.36,40.67,49.75,49.96,70.29,101.77,111.14,111.57,125.80,128.53,129.29,130.48,130.54,131.42$, 135.24, 137.12, 140.80, 141.80, 150.87, 151.51, 162.86, 168.75; Exact mass calcd for $\mathrm{C}_{36} \mathrm{H}_{32} \mathrm{~N}_{4} \mathrm{O}_{8} \mathrm{Na}_{1}$ $(\mathrm{M}+\mathrm{Na})^{+}$671.2117, found 671.2120;

2,2-Bis-[(3-benzoyl-thymin-1-yl)methyl]-1,3-propanediol (3a) A solution of 2a (6.49 g, $10 \mathrm{mmol})$ in TFA- $\mathrm{H}_{2} \mathrm{O}(3: 1,20 \mathrm{~mL})$ was allowed to stand at r.t. for $2 \mathrm{~h}$. The reaction mixture was neutralized with saturated $\mathrm{NaHCO}_{3}$ solution. Then the mixture was partitioned between EtOAc and water. The organic layer was washed with water and brine, dried over $\mathrm{MgSO}_{4}$, and then concentrated in vacuo. The residue was purified by chromatography on silica gel (hexane:EtOAc, 3:1) to give 3a $(5.10 \mathrm{~g}, 9.0 \mathrm{mmol})$ as a colourless amorphous solid in 90\% yield. ${ }^{1} \mathrm{H}$ NMR $200 \mathrm{MHz}\left(\mathrm{DMSO}_{-} \mathrm{d}_{6}\right) \delta 1.83\left(6 \mathrm{H}, \mathrm{s}, \mathrm{T}-\mathrm{CH}_{3}\right), 3.43(4 \mathrm{H}$, d, $\left.J=4.0 \mathrm{~Hz}, \mathrm{CH}_{2} \mathrm{OH}\right), 3.82\left(4 \mathrm{H}, \mathrm{s}, \mathrm{CH}_{2} \mathrm{~N}\right), 5.01(2 \mathrm{H}, \mathrm{t}, J=4.0 \mathrm{~Hz}, \mathrm{OH}), 7.53\left(4 \mathrm{H}, \mathrm{t}, J=7.7 \mathrm{~Hz}, \mathrm{Ar}_{\mathrm{m}}-\right.$ H ), 7.65(2H, br s, T-C(6)-H), $7.76\left(2 \mathrm{H}, \mathrm{t}, J=7.7 \mathrm{~Hz}, \mathrm{Ar}_{\mathrm{p}}-\mathrm{H}\right), 7.94\left(4 \mathrm{H}, \mathrm{d}, J=7.7 \mathrm{~Hz}, \mathrm{Ar}_{\mathrm{o}}-\mathrm{H}\right)$; Exact mass calcd for $\mathrm{C}_{29} \mathrm{H}_{28} \mathrm{~N}_{4} \mathrm{O}_{8} \mathrm{Na}_{1}(\mathrm{M}+\mathrm{Na})^{+}$583.1804, found 583.1794;

\section{1-O-[(4-Methoxyphenyl)diphenylmethyl]-2,2-bis-[(3-benzoyl-thymin-1-yl)methyl]-1,3-propanediol}

(4a) To a solution of 3a $(3.36 \mathrm{~g}, 6.0 \mathrm{mmol})$ in $25 \mathrm{~mL}$ of dry pyridine was added MMTrCl $(0.98 \mathrm{~g}$, $3.17 \mathrm{mmol}$ ) at $0{ }^{\circ} \mathrm{C}$ in one portion. The reaction mixture was warmed to room temperature and kept stirring overnight. The reaction mixture was concentrated and coevaporated with toluene $(2 \mathrm{x})$ in vacuo. The residue was partitioned between $\mathrm{H}_{2} \mathrm{O}$ and EtOAc. The organic layer was washed with water and brine, and concentrated in vacuo. The residue was purified by chromatography on a silica gel column $\left(\mathrm{CH}_{2} \mathrm{Cl}_{2}\right.$ : $\mathrm{MeOH}, 100: 5)$ to afford $4 \mathrm{a}(2.80 \mathrm{~g}, 3.36 \mathrm{mmol}, 56 \%)$ as a colorless amorphous solid. ${ }^{1} \mathrm{H}$ NMR $200 \mathrm{MHz}$ $\left(\mathrm{CDCl}_{3}\right) \delta 1.76\left(6 \mathrm{H}, \mathrm{s}, \mathrm{T}-\mathrm{CH}_{3}\right), 3.19\left(2 \mathrm{H}, \mathrm{s}, \mathrm{CH}_{2} \mathrm{OH}\right), 3.55\left(2 \mathrm{H}, \mathrm{br} \mathrm{s}, \mathrm{CH}_{2} \mathrm{O}\right), 3.70(2 \mathrm{H}, \mathrm{d}, J=14.3 \mathrm{~Hz}$, $\left.\mathrm{CH}_{\mathrm{a}} \mathrm{N}\right), 3.78\left(3 \mathrm{H}, \mathrm{s}, \mathrm{OCH}_{3}\right), 4.14\left(2 \mathrm{H}, \mathrm{d}, J=14.3 \mathrm{~Hz}, \mathrm{CH}_{\mathrm{b}} \mathrm{N}\right), 6.81-7.86(26 \mathrm{H}, \mathrm{m}, \mathrm{Ar}-\mathrm{H}) ;{ }^{13} \mathrm{C} \mathrm{NMR}$ $200 \mathrm{MHz}\left(\mathrm{CD}_{3} \mathrm{Cl}\right) \delta 12.23,46.98,49.87,55.18,62.01,64.28,87.62,111.02,113.36,125.32,127.53$, $128.17,128.23$, 129.05, 129.26, 130.42, 130.54, 131.39, 133.94, 135.12, 141.52, 143.44, 151.27, 159.07, 162.74, 168.66; Exact mass calcd for $\mathrm{C}_{49} \mathrm{H}_{44} \mathrm{~N}_{4} \mathrm{O}_{9} \mathrm{Na}_{1}(\mathrm{M}+\mathrm{Na})^{+}$855.3005, found 855.2998.

\section{1-O-[(4-Methoxyphenyl)diphenylmethyl]-2,2-bis-[(thymine-1-yl)methyl]-1,3-propanediol (5a)}

A solution of $4 \mathrm{a}(1.70 \mathrm{~g}, 2.0 \mathrm{mmol})$ in $\mathrm{MeOH}$ saturated with ammonia $100 \mathrm{~mL})$ was kept stirring at r.t. overnight. The mixture was concentrated, and the residue was purified by column chromatography $\left(\mathrm{CH}_{2} \mathrm{Cl}_{2}: \mathrm{MeOH}, 9: 1\right)$ to give compound $\mathbf{5 a}(0.87 \mathrm{~g}, 1.40 \mathrm{mmol})$ as a white powder in $70 \%$ yield. ${ }^{1} \mathrm{H}$ NMR 200MHz (DMSO-d6) $\delta_{\mathrm{H}} 1.67\left(6 \mathrm{H}, \mathrm{s}, \mathrm{T}-\mathrm{CH}_{3}\right), 3.10\left(2 \mathrm{H}, \mathrm{br} \mathrm{s}, \mathrm{CH}_{2} \mathrm{OH}\right), 3.14\left(2 \mathrm{H}, \mathrm{s}, \mathrm{CH}_{2} \mathrm{O}\right), 3.66(2 \mathrm{H}, \mathrm{d}, J$ $\left.=12.3 \mathrm{~Hz}, \mathrm{CH}_{\mathrm{a}} \mathrm{N}\right), 3.73\left(3 \mathrm{H}, \mathrm{s}, \mathrm{OCH}_{3}\right), 3.78\left(2 \mathrm{H}, \mathrm{d}, J=12.3 \mathrm{~Hz}, \mathrm{CH}_{\mathrm{b}} \mathrm{N}\right), 5.02(1 \mathrm{H}, \mathrm{br} \mathrm{s}, \mathrm{OH}), 6.82-7.28$ $(16 \mathrm{H}, \mathrm{m}, \mathrm{Ar}-\mathrm{H}), 11.31(2 \mathrm{H}, \mathrm{s}, \mathrm{NH}) ;{ }^{13} \mathrm{C} \mathrm{NMR} 200 \mathrm{MHz}$ (DMSO-d6) $\delta_{\mathrm{C}} 12.13,46.61,47.82,55.08$, 
$59.87,63.30,86.67,108.62,113.14,127.04,127.98,128.19,130.56,134.39,142.10,144.13,152.02$, 158.49, 164.25; Exact mass calcd for $\mathrm{C}_{35} \mathrm{H}_{35} \mathrm{~N}_{4} \mathrm{O}_{7}(\mathrm{M}-\mathrm{H})^{+}$623.2505, found 623.2508.

\section{1-O-[(4-methoxyphenyl)diphenylmethyl]-2,2-bis[(thymin-1-yl)methyl]-3-O-(P- $\beta$-cyanoethyl- $N, N$ -}

diisopropylaminophosphinyl)-1,3-propanediol (6a) The monomethoxytritylated derivative 5a (477 mg, $0.76 \mathrm{mmol})$ was dissolved in $8 \mathrm{~mL}$ of dichloromethane under argon and diisopropylethylamine $(398 \mu \mathrm{L}$, $2.29 \mathrm{mmol})$ and 2-cyanoethyl $\mathrm{N}, \mathrm{N}$-diisopropylchlorophosphoramidite $(341 \mu \mathrm{L}, 1.53 \mathrm{mmol})$ were added. The mixture slowly became clear and overall the solution was stirred for 3 hours, when TLC indicated complete reaction. Water $(2 \mathrm{~mL})$ was added, the solution was stirred for $10 \mathrm{~min}$. and partitioned between $\mathrm{CH}_{2} \mathrm{Cl}_{2}(50 \mathrm{~mL})$ and aqueous $\mathrm{NaHCO}_{3}(30 \mathrm{~mL})$. The organic phase was washed with aqueous sodium chloride $(2 \times 30 \mathrm{~mL})$ and the aqueous phases were back extracted with $\mathrm{CH}_{2} \mathrm{Cl}_{2}(30 \mathrm{~mL})$. Evaporation of the organics left a white foam which was flash purified twice on $40 \mathrm{~g}$ of silica gel (hexane: acetone: TEA, 50:49:1) to afford the product as a foam after several coevaporations with dichloromethane. Dissolution in $2 \mathrm{~mL}$ of dichloromethane and precipitation in $60 \mathrm{~mL}$ of chilled $\left(-70^{\circ} \mathrm{C}\right)$ hexane afforded $501 \mathrm{mg}(0.61$ mmol, $80 \%$ ) of the title product $6 \mathbf{a}$ as a white powder. Rf (hexane: acetone: TEA 49:49:2): 0.31.

ESI-MS pos. calcd. for $\mathrm{C}_{44} \mathrm{H}_{54} \mathrm{~N}_{6} \mathrm{O}_{8} \mathrm{P}_{1} 825.3741$ found $825.3745[\mathrm{M}+\mathrm{H}]^{+}$;

31 P-NMR $\delta$ (ppm, external ref. $=\mathrm{H}_{3} \mathrm{PO}_{4}$ capil.) 149.49 ppm;

[5,5-Bis-[(adenin-9-yl)methyl]-2-phenyl-1,3-dioxane (2b) To a solution of adenine (7.62 g, $56.4 \mathrm{mmol})$ in DMF $(200 \mathrm{~mL})$ was added sodium hydride ( $80 \%$ dispersion in mineral oil $2.26 \mathrm{~g}, 75.2 \mathrm{mmol}$ ). The mixture was stirred at $80{ }^{\circ} \mathrm{C}$ under inert atmosphere for $90 \mathrm{~min}$. Then $\mathbf{1 b}(10.0 \mathrm{~g}, 18.8 \mathrm{mmol})$ was added, and the reaction mixture was warmed to $105^{\circ} \mathrm{C}$. After 15 hours of heating, the reaction was cooled to room temperature and filtered through Celite. The filtrate was concentrated under reduced pressure. The residue was washed with EtOAc $(50 \mathrm{~mL})$ and $\mathrm{H}_{2} \mathrm{O}(150 \mathrm{~mL})$, and dried to afford $\mathbf{2 b}(4.10 \mathrm{~g}, 8.94 \mathrm{mmol}$, $48 \%$ ) as yellow powder which is pure enough for the next reaction. ${ }^{1} \mathrm{H}$ NMR $500 \mathrm{MHz}$ (DMSO-d6) $\delta_{\mathrm{H}}$ $3.82\left(2 \mathrm{H}, \mathrm{d}, J=11.9 \mathrm{~Hz}, 2 \mathrm{C}-\mathrm{CH}_{\mathrm{a}} \mathrm{O}\right), 3.96\left(2 \mathrm{H}, \mathrm{d}, J=11.8 \mathrm{~Hz}, 2 \mathrm{C}-\mathrm{CH}_{\mathrm{b}} \mathrm{O}\right), 4.20\left(2 \mathrm{H}, \mathrm{s}, \mathrm{CH}_{2}-\mathrm{N}\right), 4.67$ $\left(2 \mathrm{H}, \mathrm{s}, \mathrm{CH}_{2}-\mathrm{N}\right), 5.40(1 \mathrm{H}, \mathrm{s}, \mathrm{Ph}-\mathrm{CH}), 7.27-7.44\left(9 \mathrm{H}, \mathrm{m}, 2-\mathrm{NH}_{2}, \mathrm{Ph}-\mathrm{H}\right), 8.08(1 \mathrm{H}, \mathrm{s}, \mathrm{C}(8)-\mathrm{H}), 8.15(1 \mathrm{H}$, s, C(2)-H ), $8.22\left(1 \mathrm{H}, \mathrm{s}, \mathrm{C}\left(2^{\prime}\right)-\mathrm{H}\right), 8.42\left(1 \mathrm{H}, \mathrm{s}, \mathrm{C}\left(8^{\prime}\right)-\mathrm{H}\right) ;{ }^{13} \mathrm{C}$ NMR 500MHz (DMSO-d6) $\delta_{\mathrm{c}} 44.53,44.67$, $69.95,101.31,118.50,118.66,126.60,128.18,129.06,138.08,142.08,150.42,150.58,152.80,156.16$, 156.22, $\underline{\mathrm{C}}\left(\mathrm{CH}_{2}\right)_{4}$ ( overlapping with the DMSO peak); Exact Mass calcd for $\mathrm{C}_{22} \mathrm{H}_{23} \mathrm{~N}_{10} \mathrm{O}_{2}(\mathrm{M}+\mathrm{H})^{+}$ 459.2005, found 459.2006. 
[5,5 -Bis-[( $\mathbf{N}^{6}$-benzoyladenin-9-yl)methyl]-2-phenyl-1,3-dioxane (3b) To a solution of $2 \mathrm{~b}$ (4.00 g, 8.72 $\mathrm{mmol})$ in $100 \mathrm{~mL}$ of pyridine was added dropwise $\mathrm{BzCl}(6.0 \mathrm{~mL}, 52.3 \mathrm{mmol})$ at $0{ }^{\circ} \mathrm{C}$. The reaction mixture was warmed to room temperature and kept stirring overnight. The reaction mixture was concentrated and covaperated with $20 \mathrm{~mL}$ of toluene two times in vacuo. The residue was partitioned between $\mathrm{H}_{2} \mathrm{O}(100$ $\mathrm{mL})$ and EtOAc $(200 \mathrm{~mL})$. The organic layer was washed with water and brine, and concentrated in vacuo. The residue was purified by chromatography on a silica gel column (n-hexane:EtOAc, 1:1) to afford full protected $\mathbf{2 b}(6.09 \mathrm{~g}, 6.96 \mathrm{mmol})$ as a colorless amorphous solid in $80 \%$ yield. A solution of full protected $\mathbf{2 b}(3.50 \mathrm{~g}, 4.00 \mathrm{mmol})$ in $\mathrm{MeOH}$ saturated with ammonia $(30 \mathrm{~mL})$ was allowed to stand at 0 ${ }^{\circ} \mathrm{C}$ for half an hour. The mixture was concentrated, and the residue was purified by column chromatography $\left(\mathrm{CH}_{2} \mathrm{Cl}_{2}: \mathrm{MeOH}, 9: 1\right)$ to give compound $\mathbf{3 b}(1.87 \mathrm{~g}, 2.80 \mathrm{mmol})$ as a white powder in $70 \%$ yield. ${ }^{1} \mathrm{H}$ NMR $200 \mathrm{MHz}$ (DMSO-d6) $\delta 3.87(2 \mathrm{H}, \mathrm{d}, J=11.7 \mathrm{~Hz}, \mathrm{C}-\mathrm{CHaO}), 4.14(2 \mathrm{H}, \mathrm{d}, J=11.7$ $\left.\mathrm{Hz}, \mathrm{C}-\mathrm{CH}_{\mathrm{b}} \mathrm{O}\right), 4.41\left(2 \mathrm{H}, \mathrm{s}, \mathrm{CH}_{2}-\mathrm{N}\right), 4.85\left(2 \mathrm{H}, \mathrm{s}, \mathrm{CH}_{2}-\mathrm{N}\right), 5.44(1 \mathrm{H}, \mathrm{s}, \mathrm{Ph}-\mathrm{CH}), 7.36(5 \mathrm{H}, \mathrm{s}, \mathrm{Bz}-\mathrm{H})$, 7.46-7.66 (6H, m, Bz-H ),8.04-8.09(4H, m, Bz-H ), 8.47(1H, s, C(2)-H ), 8.69 (1H, s, C(8)-H ), 8.77 (1H, s, C(8')-H ), $8.81\left(1 \mathrm{H}, \mathrm{s}, \mathrm{C}\left(2^{\prime}\right)-\mathrm{H}\right), 11.22(2 \mathrm{H}, \mathrm{s}, \mathrm{NH}){ }^{13} \mathrm{C}$ NMR 200MHz (DMSO-d6) $\delta_{\mathrm{C}} 45.09,45.43$, 70.13, 101.33, 125.16, 125.31, 126.68, 128.26, 128.68, 129.10, 132.66, 133.63, 138.06, 145.86, 146.01, $150.47,151.90,153.54,153.69,165.83, \underline{C}\left(\mathrm{CH}_{2}\right)_{4}$ (overlapping with the DMSO peak); Exact Mass calcd for $\mathrm{C}_{36} \mathrm{H}_{31} \mathrm{~N}_{10} \mathrm{O}_{4}(\mathrm{M}+\mathrm{H})^{+}$667.2530, found 667.2536;

2,2-Bis-[(N $\mathbf{N}^{6}$-benzoyladenin-9-yl)methyl]-1,3-propanediol (4b) A solution of $\mathbf{3 b}$ (1.87 g, $\left.2.80 \mathrm{mmol}\right)$ in TFA- $\mathrm{H}_{2} \mathrm{O}(3: 1,10 \mathrm{~mL})$ was allowed to stand at r.t. for $2 \mathrm{~h}$. The reaction mixture was neutralized with saturated $\mathrm{NaHCO}_{3}$ solution. Then the mixture was partitioned between the EtOAc and water. The organic layer was washed with water and brine, dried over $\mathrm{MgSO}_{4}$, and then concentrated in vacuo. The residue was purified by chromatography on silica gel $\left(\mathrm{CH}_{2} \mathrm{Cl}_{2}: \mathrm{MeOH}, 20: 1\right)$ to give $\mathbf{4 b}(1.50 \mathrm{~g}, 2.6 \mathrm{mmol})$ as a colorless amorphous solid in $92.6 \%$ yield. ${ }^{1} \mathrm{H}$ NMR $200 \mathrm{MHz}$ (DMSO- $d 6$ ) $\delta_{\mathrm{H}} 3.36(4 \mathrm{H}, \mathrm{s}$ (overlapped by water peak), $\left.\mathrm{CH}_{2} \mathrm{O}\right), 4.43\left(4 \mathrm{H}, \mathrm{s}, \mathrm{CH}_{2}-\mathrm{N}\right), 5.22(2 \mathrm{H}$, apparent $\mathrm{t}, \mathrm{OH}), 7.52-7.66(6 \mathrm{H}, \mathrm{m}, \mathrm{Bz}-\mathrm{H}), 8.05$ $(4 \mathrm{H}, \mathrm{d}, J=7.0 \mathrm{~Hz}, \mathrm{Bz}-\mathrm{H}), 8.45(2 \mathrm{H}, \mathrm{s}, \mathrm{C}(8)-\mathrm{H}), 8.73$ (2H, s, C(2)-H ), 11.19 (2H, s, NH ); ${ }^{1} \mathrm{H}$ NMR $200 \mathrm{MHz}\left(\mathrm{DMSO}-d 6+\mathrm{D}_{2} \mathrm{O}\right) \delta_{\mathrm{H}} 3.31(4 \mathrm{H}, \mathrm{s}, \mathrm{CH} 2 \mathrm{OH}), 4.41\left(4 \mathrm{H}, \mathrm{s}, \mathrm{CH}_{2}-\mathrm{N}\right), 7.52-7.60(6 \mathrm{H}, \mathrm{m}, \mathrm{Bz}-\mathrm{H})$, 7.97 - 8.02 (4H, m, Bz-H ), 8.43 (2H, s, C(8)-H ), 8.69 (2H, s, C(2)-H ); ${ }^{13} \mathrm{C}$ NMR 200MHz (DMSO-d6) $\delta_{\mathrm{C}} 44.27,46.70,61.21,125.04,128.68,132.66,133.63$, 145.98, 150.44, 151.78, 153.45, 165.83; Exact Mass calcd for $\mathrm{C}_{29} \mathrm{H}_{26} \mathrm{~N}_{10} \mathrm{O}_{4} \mathrm{Na}_{1}(\mathrm{M}+\mathrm{Na})^{+}$601.2036, found 601.2029;

\section{1-O-[(4-Methoxyphenyl)diphenylmethyl]-2,2-Bis-[( $\mathrm{N}^{6}$-benzoyladenin-9-yl)methyl]-1,3-propanediol}

(5b) To a solution of $\mathbf{4 b}(1.49 \mathrm{~g}, 2.58 \mathrm{mmol})$ in $15 \mathrm{~mL}$ of dry pyridine was added $\mathrm{MMTrCl}(0.98 \mathrm{~g}, 3.17$ $\mathrm{mmol})$ at $0{ }^{\circ} \mathrm{C}$ in one portion. The reaction mixture was warmed to room temperature and kept stirring 
overnight. The reaction mixture was concentrated and co-evaporated with toluene $(2 \mathrm{x})$ in vacuo. The residue was partitioned between $\mathrm{H}_{2} \mathrm{O}$ and EtOAc. The organic layer was washed with water and brine, and concentrated in vacuo. The residue was purified by chromatography on a silica gel column $\left(\mathrm{CH}_{2} \mathrm{Cl}_{2}: \mathrm{MeOH}, 40: 1\right)$ to afford $\mathbf{5 b}(1.20 \mathrm{~g}, 1.41 \mathrm{mmol})$ as a colorless amorphous solid in $54.6 \%$ yield. ${ }^{1} \mathrm{HNMR} \quad 500 \mathrm{MHz}$ (DMSO-d6) $\delta_{\mathrm{H}} 3.14\left(2 \mathrm{H}, \mathrm{s}, \mathrm{CH}_{2} \mathrm{OH}\right.$ ), 3.30-3.34 (2H, obscured by HO-D, $\mathrm{CH}_{2} \mathrm{O}$ ), $3.71\left(3 \mathrm{H}, \mathrm{s}, \mathrm{CH}_{3} \mathrm{O}\right), 4.43\left(2 \mathrm{H}, \mathrm{d}, J=14.4, \mathrm{CH}_{\mathrm{a}}-\mathrm{Ad}\right), 4.50\left(2 \mathrm{H}, \mathrm{d}, J=14.4 \mathrm{~Hz}, \mathrm{CH}_{\mathrm{b}}-\mathrm{Ad}\right), 5.38(1 \mathrm{H}$, br s, $\mathrm{OH}), 6.78(2 \mathrm{H}, \mathrm{d}, J=8.8 \mathrm{~Hz}, \mathrm{Ar}-\mathrm{H}), 6.96(2 \mathrm{H}, \mathrm{d}, J=8.8 \mathrm{~Hz}, \mathrm{Ar}-\mathrm{H}), 7.14-7.25(12 \mathrm{H}, \mathrm{m}, 2 \mathrm{NH}$ and 10 Ar-H ), 7.54-7.66 (6H, m, Bz-H ), 8.06 (4H, d, J= 7.8 Hz, Bz-H ), 8.25 (2H, s, C(8)-H ), 8.66 (2H, s, $\mathrm{C}(2)-\mathrm{H})$; Exact Mass calcd for $\mathrm{C}_{49} \mathrm{H}_{41} \mathrm{~N}_{10} \mathrm{O}_{5}(\mathrm{M}-\mathrm{H})^{+}$849.3261, found 849.3268;

\section{1-O-[(4-Methoxyphenyl)diphenylmethyl]-2,2-bis [( $N^{6}$-benzoyladenin-9-yl $)$ methyl $]-3-O-(P-b-$} cyanoethyl- $N, N$-diisopropylaminophosphinyl)-1,3-propanediol (6b) The monomethoxytritylated derivative $5 \mathbf{b}(317 \mathrm{mg}, 0.37 \mathrm{mmol})$ was dissolved in $6 \mathrm{~mL}$ of dichloromethane under argon and diisopropylethylamine (194 $\mu \mathrm{L}, 1.12 \mathrm{mmol})$ and 2-cyanoethyl $\mathrm{N}, \mathrm{N}$-diisopropylchlorophosphoramidite (166 $\mu \mathrm{L}, 0.74 \mathrm{mmol})$ were added and the solution was stirred for 2 hours, when TLC indicated complete reaction. Water $(2 \mathrm{~mL})$ was added, the solution was stirred for $10 \mathrm{~min}$. and partitioned between $\mathrm{CH}_{2} \mathrm{Cl}_{2}$ $(50 \mathrm{~mL})$ and aqueous $\mathrm{NaHCO}_{3}(30 \mathrm{~mL})$. The organic phase was washed with aqueous sodium chloride $(2 \times 30 \mathrm{~mL})$ and the aqueous phases were back extracted with $\mathrm{CH}_{2} \mathrm{Cl}_{2}(30 \mathrm{~mL})$. Evaporation of the organics left a light yellow foam which was flash purified twice on $40 \mathrm{~g}$ of silica gel (hexane: acetone: TEA, 60:39:1) to afford the product as a foam after several coevaporations with dichloromethane. Dissolution in $2 \mathrm{~mL}$ of dichloromethane and precipitation in $60 \mathrm{~mL}$ of chilled $\left(-70^{\circ} \mathrm{C}\right)$ hexane afforded $202 \mathrm{mg}(0.19 \mathrm{mmol}, 52 \%)$ of the title product $\mathbf{6 b}$ as a white powder. Rf (hexane: acetone: TEA 49:49:2): 0.50 .

ESI-MS pos. calcd. for $\mathrm{C}_{58} \mathrm{H}_{60} \mathrm{~N}_{12} \mathrm{O}_{6} \mathrm{P}_{1} 1051.4496$ found $1051.4491[\mathrm{M}+\mathrm{H}]^{+}$;

${ }^{31} \mathrm{P}-\mathrm{NMR} \delta$ (ppm, external ref. $=\mathrm{H}_{3} \mathrm{PO}_{4}$ capil.) $149.52 \mathrm{ppm}$;

\section{OLIGONUCLEOTIDE SYNTHESIS}

Oligonucleotide assembly was performed on an Expedite ${ }^{\mathrm{TM}}$ DNA synthesiser (Applied Biosystems) by using the phosphoramidite approach. The standard DNA assembly protocol was used, except for $5 \mathrm{~min}$ coupling time using $0.08 \mathrm{M}$ of the newly synthesized unnatural amidites. The oligomers were deprotected and cleaved off from the solid support by treatement with concentrated aqueous ammonia $\left(55^{\circ} \mathrm{C}, 16 \mathrm{~h}\right)$. After gel filtration on a NAP-10 ${ }^{\circledR}$ column (Sephadex G25-DNA grade; Pharmacia) with water as eluent, the crude product was analyzed on a Mono-Q ${ }^{\circledR}$ HR 5/5 anion exchange column, after which purification 
was achieved on a Mono- $\mathrm{Q}^{\circledR}$ HR 10/10 column (Pharmacia) with the following gradient system ( $\mathrm{A}=10$ $\mathrm{mM}$ TrisHCl pH 7.4, $10 \mathrm{mM} \mathrm{NaClO} 4,15 \% \mathrm{CH}_{3} \mathrm{CN}$; $\mathrm{B}=10 \mathrm{mM}$ TrisHCl pH 7.4, $600 \mathrm{mM} \mathrm{NaClO} 4,15 \%$ $\mathrm{CH}_{3} \mathrm{CN}$; gradient used dependent on the oligo; flow rate $2 \mathrm{ml} / \mathrm{min}$ ). For sequences with multiple successive $\mathrm{T}^{*}$ analogues, the aggregates could be disrupted by running the purification at basic $\mathrm{pH}(\mathrm{A}=10$ $\mathrm{mM} \mathrm{NaOH}, \mathrm{pH}$ 12.0, 0.1 M NaCl; $\mathrm{B}=10 \mathrm{mM} \mathrm{NaOH}, \mathrm{pH}$ 12.0, $0.9 \mathrm{M} \mathrm{NaCl}$ ). The low-pressure liquid chromatography system consisted of a Merck-Hitachi L 6200 A intelligent pump, a Mono $\mathrm{Q}^{\circledR}$-HR 10/10 column (Pharmacia), a Uvicord SII 2138 UV detector (Pharmacia-LKB) and a recorder. The productcontaining fraction was desalted on a NAP- $10^{\circledR}$ column and lyophilized.

Oligonucleotides were characterized and their purity was checked by HPLC/MS on a capillary chromatograph (CapLC, Waters, Milford, MA). Columns of $150 \mathrm{~mm}$ x $0.3 \mathrm{~mm}$ length (LCPackings, San Francisco, CA) were used. Oligonucleotides were eluted with a triethylammonium-1,1,1,3,3,3hexafluoro-2-propanol: acetonitrile solvent system. Flow rate was $5 \mu \mathrm{L} / \mathrm{min}$. Electrospray spectra were acquired on an orthogonal acceleration / time-of-flight mass spectrometer (Q-Tof-2, Micromass, Manchester, UK) in negative ion mode. Scan time used was 2 sec. The combined spectra from a chromatographic peak were deconvoluted using the MaxEnt algorithm of the software (Masslynx 3.4, Micromass, Manchester, UK). Oligonucleotide masses were calculated using the monoisotopic element masses.

\section{MELTING TEMPERATURES}

Oligomers were dissolved in $0.1 \mathrm{M} \mathrm{NaCl}, 0.02 \mathrm{M}$ potassium phosphate, $\mathrm{pH} 7.5,0.1 \mathrm{mM}$ EDTA. The concentration was determined by measuring the absorbance in MilliQ water at $260 \mathrm{~nm}$ at $80{ }^{\circ} \mathrm{C}$ and assuming the acyclic nucleoside analogues to have the same extinction coefficients in the denatured state as the natural nucleosides $\left(\mathrm{A}^{*}, \varepsilon=15000 ; \mathrm{T}^{*} \varepsilon=8500\right)$. The concentration in all experiments was $4 \mu \mathrm{M}$ for each strand unless otherwise stated. Melting curves were determined with a Varian Cary 300 BIO spectrophotometer. Cuvettes were maintained at constant temperature by means of water circulation through the cuvette holder. The temperature of the solution was measured with a thermistor directly immersed in the cuvette. Temperature control and data acquisition were done automatically with an IBMcompatible computer using Cary WinUV thermal application software. The samples were heated at a rate of $0.2{ }^{\circ} \mathrm{C} / \mathrm{min}$ starting at $10{ }^{\circ} \mathrm{C}$ up to $80{ }^{\circ} \mathrm{C}$ and cooling again at the same speed. Melting temperatures were determined by plotting the first derivative of the absorbance versus temperature curve and are the average of two runs. Up and down curves in general showed identical $\mathrm{T}_{\mathrm{m}}$ values. 


\section{MOLECULAR MODELLING}

The duplex used for model building has the sequence 5'-(GCATAT*CACTGG)-3' with its complement, with $\mathrm{T}^{*}$ representing the modified nucleotide. The monomer $\mathrm{T}^{*}$ with a double headed thymine base was created using Macromodel 5.0 and the geometry was optimised with the Amber* force field. The atomic charges of $\mathrm{T}^{*}$ to be used in the Amber calculations were obtained from a gamess run followed by a resp calculation. The parameter database used in Amber is the 1999 parameter set. The monomer was then fitted ${ }^{15}$ onto the residue 6 of the above B-duplex which was first created by the Nucgen program in the amber 6.0 package. The energy of the resulting duplex was then minimized, while restraining the Watson-Crick hydrogen bonds and by fixing the positions of the non-modified nucleotides. An amount of 22 counterions $(\mathrm{Na}+)$ were added and the duplex was inserted in a box of TIP3P waters ${ }^{16}$ with initial dimensions $52 \times 51 \times 71 \AA$. The solvent around the duplex was then relaxed by a short energy minimisation (1000 steps) in the Sander program. A molecular dynamics run of $500 \mathrm{ps}$ at $300 \mathrm{~K}$ was started. All Sander MD calculations were performed with Sander using periodic boundary conditions and using the particle mesh Ewald method for the summation of the coulombic interactions. The final $100 \mathrm{ps}$ were used to calculate an average structure as well as the atomic fluctuations (Figure 1).

The fluctuations around atom number 1, 400 and 790 in Figure 1 are a consequence of the end of chain movements. The fluctuations, however, around 200 (the incorporated $\mathrm{T}^{*}$ residue) must be attributed to the higher flexibility of this residue lacking the backbone of a 5-ring sugar. A hydrogen bond analysis does not give an indication of broken or missing hydrogen bonds in the duplex.

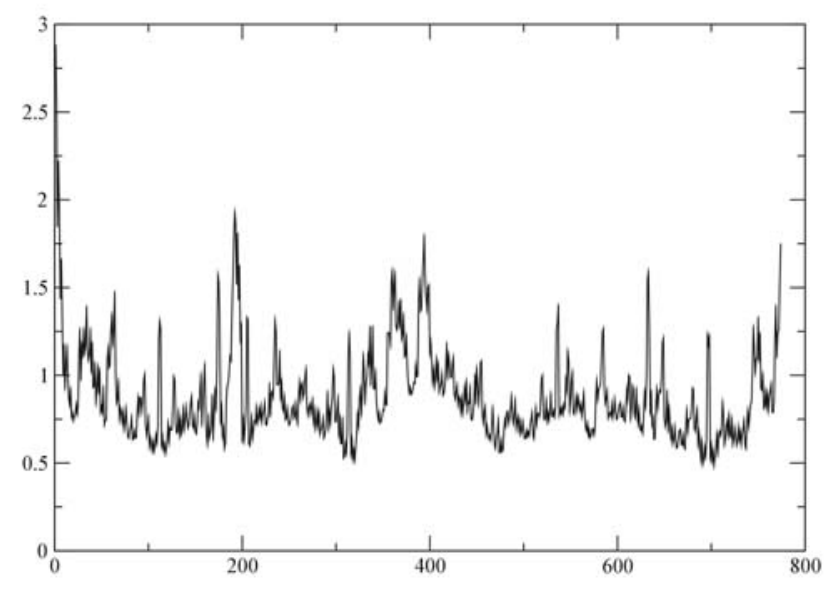

Figure 1 Atomic fluctuations $\left(\mathrm{A}^{2}\right)$ of the structures from the last $100 \mathrm{ps}$ of a 500 ps molecular dynamics simulation, as a function of the atom number. 